so exceedingly close a resemblance that no decided specific distinction has yet been satisfactorily pointed out, however probable it may be that such distinction may exist.

Why, therefore, the one should be popularly styled a "wild Horse," and the other a "wild Ass," it is difficult to comprehend. Even Pallas terms the Dshiggetai " un Cheval sauvage," though describing it as "ni Cheval ni Ane;" while the other he both designates as the Ass of the steppes and as the "Cheval ou Ane," employing the word "cheval " in its German equivalent evidently in the sense of equus. Col. Chesney, as we have seen, terms the Arabian A. hemippus a "wild Horse," as distinguished from his wild Ass of South Arabia! The fact is, I apprehend, that the vague application of these names has resulted merely from the eolouring.

XXXII.-Descriptions of new Genera and Species of Tenthredinidæ in the Collection of the British Museum. By Frederick Sмiтh.

The collection of Tenthredinidæ contained in the national Museum is perhaps the most extensive in Europe; the species described in the present paper are, in my own opinion, the most remarkable in the various genera to which they belong. The Hylotoma imperialis is unrivalled both in size and beauty by any of the species of that extensive genus. The new Lyda is the first species which I have seen from the East, and is remarkable for the extreme elongation of the antennæ. The new genus Derecyrta is, however, the finest addition to the family. The new species of Sirex must acquire additional interest from the fact of its being discovered in the cedars of Lebanon. Having been engaged in the preparation of a Catalogue of the Tenthredinidæ for some time past, and it being obvious that its completion will occupy still a considerable length of time, I have thought it desirable to secure to myself the description of a few of the more remarkable species and genera of this family of insects.

Genus Нуцотома; Latr.

\title{
Hylotoma imperialis.
}

$H$. nitens, supra purpureo-violacea; capite, thorace abdomineque infra nigro-chalybeis ; alis flavo-hyalinis ; antennis nigris, opacis.

Female. Length 8 lines. Brilliant purple, with violet tints above, varying in different lights ; beneath of a steel blue, very smooth and shining; the antennæ of an opake black; the wings yellow hyaline, the nervures reddish-yellow.

Hab. North China. Robert Fortune Esq. 


\section{Genus LYDA, Fabr.}

\section{Lyda flagellicornis.}

$\boldsymbol{L}$. melleo-flava; antennis prælongis, apice graduatim attenuatis ; alis pallide flavo-hyalinis, apice fusco late terminato.

Female. Length 5 lines. Darkish honey-yellow, șmooth and shining; the antennæ longer than the body, setaceous; the scape, basal joint of the flagellum, and the joints (12-18) yellow, the rest of a blackish brown; the region of the ocelli and middle of the pectus black; the wings pale yellowish-hyaline, their apex broadly fuscous.

Hab. North China. Robert Fortune, Esq.

\section{Genus Derecyrta.}

Head subglobose, the vertex swollen or convex; the eyes lateral, large and ovate; the ocelli prominent, and placed in a triangle between the eyes; the antenne setaceous, composed of 23 joints ; the scape short, curved, and slightly thickened towards the apex ; the first joint of the flagellum half the length of the scape, the second as long as the scape, the third and four following joints as long as the first; the remaining joints are each in succession shorter than the preceding. Thorax as wide as the head, oblong, the sides parallel; the prothorax narrowed anteriorly into a short neck; the mesothorax slightly elevated in front; the scutellum elevated; the anterior wings with one marginal and four submarginal cells; the marginal cell elongate, with a short appendix at the apex; the first submarginal cell small, the second oblong, widest at the apex, the third subquadrate, the fourth extending to the apex of the wing; the second and third cells each receive a recurrent nervure a little within near their base; the tibiæ bispinose at their apex. Abdomen cylindrical, about twice the length of the head and thorax; the ovipositor short, and slightly exserted.

\section{Derecyrta pictipennis.}

D. ochracea, nitida ; capite, abdominis apice, antennis pedibusque nigris ; alis fuscis, basi fasciaque transversali flavo-hyalinis.

Female. Length 9 lines. Head shining black, smooth and impunctate behind the ocelli, coarsely and irregularly striated before them; the mandibles short, stout, and armed with three acute teeth, striated externally. Thorax ochraceous, shining; the mesothorax with three deep longitudinal grooves, the spaces between them transversely and coarsely striated, beyond the grooves finely punctured; the scutellum and metathorax finely punctured; wings brown, their base flavo-hyaline; a broad flavohyaline fascia crosses the wings at the base of the marginal cell; 
the legs black. Abdomen ochraceous; the four apical segments black, the first of the black ones tinged with reddish yellow in the middle; the sides of the abdomen have also a slight reddish tinge.

Captured by Mr. H. W. Bates at Ega, Brazil.

This species is unique in the National Collection, and was acquired in 1858, since which period it has been ticketed as a new undescribed genus; it is certainly the finest addition that has been made to the family Xiphydriidæ for many years.

Genus Sirex, Linn.

\section{Sirex cedrorum.}

S. capite nigro, pone oculos flavo; pedibus flavis, femoribus basi tibiisque apice nigris; abdomine supra fascia nigra ante apicem.

Female. Length 1 inch. Black; the head with thin black pubescence; the base of the mandibles and anterior margin of the clypeus obscurely ferruginous ; the antennæ and head behind the eyes luteous. Thorax rugose, with the pro- and mesothorax laterally obscurely testaceous, thinly covered with short black pubescence; wings yellowish-hyaline, with the nervures and costa ferruginous; the posterior femora and the base of the anterior and intermediate pair black; the posterior tibiæ black, with their base yellow. Abdomen with a silky gloss; the two basal segments, and a narrow fascia at the base of the seventh, yellow; the eighth and ninth segments yellow, the former with a black fascia at its apical margin, which extends narrowly over the base of the apical segment.

This species was found in a portion of the trunk of one of the cedars of Mount Lebanon; it closely resembles the Sirex gigas, but appears to be distinguished by too many differences to constitute a variety of that insect; the most prominent differences are the head being entirely yellow behind the eyes, the posterior tibiæ nearly entirely black, and the abdomen having a black fascia at its apex; the anterior margin of the clypeus is slightly produced in the middle, and very coarsely punctured; in S. gigas it is finely roughened, with its margin smooth and rounded. The male differs from the same sex of $S$. gigas in having only the extreme base of the abdomen and the apical segment black; the head is also entirely yellow behind the eyes.

\section{Genus Cladomacra.}

Antenna composed of sixteen joints, pectinated and pilose; head transverse; eyes ovate and very prominent. Wings ample, the anterior pair with one marginal and four submarginal cells, the first subovate and smaller than the second, the second and 
third cells oblong, the fourth extending to the apex of the wing. Legs simple, elongate; the tibiæ armed with two short spines at their apex.

\section{Cladomacra macropus.}

C. nigra ; capite, thorace, abdominis basi, coxis femoribusque rufotestaceis; antennis elongatis, pectinatis; alis fumatis, venis fuscis.

Male. Length 3 lines. Black; the head, thorax, and extreme base of the abdomen rufo-testaceous; the head with a deep depression on each side; the antennæ emanating from a short basal footstalk, one-third longer than the body, and pectinate; the teeth or branches elongate and pilose. The wings of a smoky brown, iridescent, with the nervures dark brown. The legs longer than the body; the coxæ, trochanters, anterior and intermediate femora, the base of the posterior pair, and the anterior and intermediate tibiæ inside, rufo-testaceous; the posterior tibiæ and tarsi with short black pubescence.

This beautiful insect, for which I am obliged to establish a new genus, has been received from $\mathrm{Mr}$. Wallace, who captured it in Celebes; the neuration of the wings, and general habit of the species, appear to indicate clearly its affinity to the genera Cladius, Trichiocampus, and Nematus, from all of which it is separated by having four submarginal cells, and antennæ composed of sixteen joints. The normal number in the Tenthredinidæ is nine joints; but there are several genera which depart from that number : thus, in Sirex there are twenty-five, in Xiphydria thirteen, whilst in Lyda the number varies, in the different species, from twenty-one to thirty-four.

XXXIII.-Descriptions of Freshwater Shells collected in Southern India by Lieut. Charles Annesley Benson, 45th M.N.I. By W. H. Benson, Esq.

THe following shells were discovered at Quilon, on the Malabar coast, in the territory of Travancore, a portion of country which appears hitherto to have escaped the researches of conchologists. Among other species, the little-known Melania Riquetii, De Grateloup (figured and described by that author in the 'Acts' of the Nat. Hist. Society of Bordeaux), from Bombay, was found to accord perfectly with the published type, which appears to have been subsequently described by Lea under the designation of M. Tornatella. The figure in the 'Iconica' $(173 b)$ delineates the sculpture of $M$. Riquetii, while that given at $173 a$ agrees better with Souleyet's M. sculpta, a species which was found by the late Dr. Bacon at Singapore. I have seen one of the numerous varieties of Melania lirata, B. (J. A. S. 1836, sub- 


\section{$2 \mathrm{BHL}$ Biodiversity Heritage Library}

Smith, Frederick. 1860. "XXXII.-Descriptions of new genera and species of Tenthredinidæ in the collection of the British Museum." The Annals and magazine of natural history; zoology, botany, and geology 6, 254-257.

View This Item Online: https://www.biodiversitylibrary.org/item/19439

Permalink: https://www.biodiversitylibrary.org/partpdf/15694

\section{Holding Institution}

Natural History Museum Library, London

\section{Sponsored by}

Natural History Museum Library, London

\section{Copyright \& Reuse}

Copyright Status: Public domain. The BHL considers that this work is no longer under copyright protection.

This document was created from content at the Biodiversity Heritage Library, the world's largest open access digital library for biodiversity literature and archives. Visit BHL at https://www.biodiversitylibrary.org. 